Судебный процесс должен быть последним этапом в применении мирных способов урегулирования и разрешения международных споров и конфликтов. Итак, у государств - участников спора, конфликта всегда есть возможность выбора способа преодоления разногласия и противоборства. Они могут достигнуть соглашения путем прямых переговоров либо с помощью посредников, могут обратиться за разрешением конфликта к арбитру, в третейский суд, исходя из того, что подчинятся его решению и выполнят это решение добровольно, либо в международный суд.

${ }^{1}$ Mitchell C.R. The Structure of International Conflict.- L., 1981.P. 122-123.

'De Reuck A. The Logic of Conflict: Its Origin. Development and Resolution // Conflict in World Society. A New Perspective on International Relations / Ed. by M. Banks.- L., 1984.- P. 96-111.

${ }^{3}$ Левин Д.Б. Принцип мирного разрешения международных споров.M., 1977.- С. 60.

${ }^{4} \mathrm{CM}$. Lewi W. International Politics: Foundations of System.- Minneapolis, 1974.- P. 171.

s Ibid.

${ }^{6}$ Mitchell C.R. Op.cit.- P. 46.

Статья поступила в редакцию в сентябре 1997 г.

\title{
ПОНЯТИЕ И ПРОТИВОПРАВНОСТЬ НАЕМНИЧЕСТВА
}

В.В. Але шин*

Участие наемников в вооруженных конфликтах, их использование для вмешательства во внутренние дела, угрозы территориальной целостности и независимости суверенных государств, воспрепятствования процессу самоопределения народов, подрыва международного мира и безопасности вызвали негативное отношение $\mathrm{K}$ такому явлению, как наемничество.

История найма иностранных граждан для укрепления армий иностранных государств связана с созданием вооруженных сил и

* Кандидат юридических наук. 
вооруженньми конфликтами. В Древнем Египте воины из Ливии составляли боеспособную часть армии феодалов. Наемную армию содержала купеческая республика Карфаген. Были наемные воины и на Руси. В 944 году князь Игорь, направляясь к Царь-граду, предварительно укрепил свое войско печенегами. Болгары сообшали императору Роману: "Идут русские наняли и печенегов".

В средние века наемники использовались для борьбы с восстаниями городской бедноты и крестьян. В мае 1358 года на северо-востоке Франции при участии наемников было подавлено крестьянское восстание под предводительством Гильома Каля, известное в истории под названием Жакерия. В 1381 году английский король Ричард II, опираясь на английских рыцарей и наемных солдат, учинил жестокую расправу над восставшими под руководством Уота Тайлера ${ }^{2}$.

В XVII-XVIII веках цари привлекали в русскую армию иностранцев. При Федоре Иоанновиче в русской армии служили немцы, поляки, литовцы, шотландцы, датчане, шведы, греки ${ }^{3}$. Русской армией Петра I в боях под Нарвой командовал бывший генерал австрийской армии, а офицеры-иностранцы были обычным явлением в петровскую эпоху.

Исторические факты свидетельствуют о том, что в разные эпохи в армиях различных государств и предводителей служили иностранцы. Однако важно отметить, что, во-первых, наемничество в то время не рассматривалось как противоправное деяние, а во-вторых, иностранных граждан, проходивших службу в армиях других суверенных государств, следовало бы рассматривать как военнослужащих-контрактников, то есть лиц, которые проходят военную службу на основе заключенного контракта (соглашения), в котором закрепляются права и обязанности сторон. Возможность прохождения военной службы в армии другого государства должна быть закреплена национальным законодательством (указом, манифестом и т.д.). Примером может служить изданный в 1702 году Петром I Манифест о вызове иностранцев на службу в Россию, обещавший им хорошие условия, охрану прав и свободу совести

\section{II}

С течением времени укреплялись государства, их вооруженные силы и спецслужбы, становились более изошренными методы и средства ведения войны. Вместе с тем зарождался и укреплялся противоправный институт наемничества, который в полной мере заявил о себе в период распада колониальной системы. В начале 60 -х годов наемнихи направлялись в Конго (Заир) под предлогом защиты бельгийцев. Однако при их активной помощи сепаратист Чомбе сверг законное правительство Патриса Лумумбы. В 70-х годах реак- 
ционные круги использовали наемников против Анголы, Бенина и ряда других государств.

Деятельность наемников проявилась в период вооруженного противостояния в Чечне. В августе 1996 года на совещании руководящего состава экстремистских группировок из Судана, Эфиопии, Сомали, Йемена, проведенном в Могадишо (Сомали) иранскими эмиссарами, было решено перебросить в Чечню в течение осени 1996 года от 500 до 700 боевиков из арабских стран, Афганистана, Пакистана. В настоящее время в Турции действует Северо-Кавказская черкесская община (СКЧО), которая объединяет 44 организации численностью 1,5 млн. человек. В нее входят черкесы, кабардинцы, чеченцы, адыгейцы. В ходе конфликта в Чечне представители общины неоднократно выезжали в районы боевых действий. Кроме того, имеются данные о том, что представители СКЧО занимались вербовкой наемников для чеченских вооруженных формирований 5 .

В сознании человечества наемничество всегда рассматривалось как глубоко безнравственное явление. Поэтому проведение в Луанде судебного процесса над группой наемников было воспринято как справедливая акция. В июне 1976 года в Луанде был начат судебный процесс в отношении английских и американских наемников. Этот процесс дал важный материал не только для становления правовой нормы об уголовной ответственности наемников. Он показал противоправность деятельности тех государств, которые способствовали и поощряли наемничество 6 .

В известном труде "О войне" $K$. Клаузевиц отмечает, что война всегда вытекает из политического положения и вызывается лишь политическими мотивами. Она представляет собой политический акт. Война - это подлинное орудие политики, продолжение политических отношений, проведение их другими средствами'. Однако государства ограничены в выборе средств и методов ведения войны. Согласно ст. 35 Дополнительного протокола к Женевским конвенциям от 12 августа 1949 г., касающегося защиты жертв международных вооруженных конфликтов (Протокол I от 8 июня 1977 г.), право сторон, находящихся в конфликте, выбирать методы и средства ведения войны не является неограниченньм. Данная международноправовая норма подтвердила сушествование в международном праве принципа, который ограничивает воююших в выборе средств и методов ведения войны, сформированного в Декларации об отмене употребления взрывчатых и зажигательных пуль 1868 года и Конвенции (IV) о законах и обычаях сухопутной войны (Гаага) 1907 года. Использование наемников для достижения конкретных политических целей, проведение политики, выгодной определенной реакционной группе лиц, с точки зрения современного международного права является противоправным и уголовно наказуемьм деянием. 
Представляется убедительной точка зрения австралийского юриста X. Бурместера относительно того, что использование наемников в условия х нового правового порядка, установленного Уставом ООН, в вооруженных конфликтах следует рассматривать как иностранную интервенцию, хотя третье государство прямо и не вовлечено в конфликт и не одобрило использование своих граждан в качестве наемников ${ }^{8}$.

\section{III}

Международно-правовыми документами, запрещающими наемничество, являются акты, принятые Организацией африканского единства (OAE), среди которых - резолюция о наемниках, одобренная Ассамблеей ОАЕ в городе Киншаса 14 сентября 1969 г., резолюция VII Чрезвычайной сессии Совета министров ОАЕ, состоявшейся в Лагосе в 1970 году, Декларация о деятельности наемников в Африке, принятая в Аддис-Абебе в июне 1971 года. В этих документах наемничество квалифицируется как орудие преступления колониалистской политики, указывается на то, что наемники представляют собой серьезную угрозу миру и безопасности, территориальной целостности ${ }^{9}$.

Организация Объединенных Наций рассматривала и неоднократно обсуждала вопросы, связанные с противоправностью наемничества. К международно-правовым актам, принятым ООН, следует отнести резолюцию Генеральной Ассамблеи № 2465 "Осушествление Декларации о предоставлении независимости колониальным странам и народам" (1968 г.), Декларацию о принципах международного права, касающихся дружественных отношений и сотрудничества между государствами в соответствии с Уставом ООН (1979 г.), Резолюцию об основных принципах правового режима комбатантов, борющихся против колониального и иностранного господства и расистских режимов (1973 г.), Резолюцию Генеральной Ассамблеи “Определение агрессии" (1974 г.), Декларацию о недопустимости интервенции и вмешательства во внутренние дела государств (1981 г.), Декларацию об усилении эффективности принципа отказа от угрозы силой или ее применения в международных отношениях (1987 г.). Из указанных актов вытекают три основных требования: а) принять законы, объявлюшие набор, финансирование и обучение наемников на территории государств преступлением; б) запретить своим гражданам службу в качестве наемников; в) воздерживаться от организации, подстрекательства, пособничества и участия в действиях, связанных с наемничеством.

В декабре 1989 года Генеральная Ассамблея ООН одобрила Конвенцию о борьбе с вербовкой, использованием, финансированием и 
обучением наемников (в силу пока не вступила). Статья 5 этой конвенции закрепляет положение, согласно которому государства не вербуют, не используют, не финансируют и не обучают наемников и запрещают такую деятельность.

Закрепление в источниках права вооруженных конфликтов положения о том, что использование наемников - это уголовное преступление, означает, что осуждаются не действия (поведение) наемников, а поведение государства. Действия государства, которое посылает наемников в другую страну или терпимо относится $\mathrm{K}$ вербовке и деятельности наемников - своих граждан, должны рассматриваться ках противоправные. Тот факт, что в документах ООН употребляется слово “использование", резюмирует международноправовую ответственность государства, в интересах которого действуют наемники ${ }^{10}$.

Впервые содержание понятия "наемник” раскрывается в ст. 47 Протокола I. Наемник - это любое лицо, которое: специально завербовано на месте или за границей для того, чтобы сражаться в вооруженном конфликте; фактически принимает непосредственное участие в военных действиях, руководствуясь главным образом желанием получить личную выгоду, и которому в действительности обещано стороной или по поручению стороны, находящейся в конфликте, материальное вознаграждение, существенно превышающее вознаграждение, обещанное или выплачиваемое комбатантам того же ранга и функций, входящим в личный состав вооруженных сил данной стороны; не является ни гражданином стороны, находящейся в конфликте, ни ллицом, постоянно проживающим на территории, контролируемой стороной, находящейся в конфликте; не входит в личный состав вооруженных сил стороны, находящейся в конфликте; не послано государством, которое не является стороной, находящейся в конфликте, для выполнения официальных обязанностей в качестве лица, входящего в состав его вооруженных сил.

Положения Конвенции о борьбе с вербовкой, использованием, финансированием и обучением наемников 1989 года (далее: Конвенция 1989 г.) детализируют термин "наемних" и захрепляют, что наемником является также лицо, которое специально завербовано на месте или за границей для участия в совместныХ насильственныХ действиях, направленных на свержение правительства или иной подрыв конституциснного порядка или подрыв территориальной целостности государства (п. 2 ст. I).

Таким образом, термином “наемних" охватывается не только лицо, специально завербованное для того, чтобы сражаться в вооруженном конфликте, и непосредственно участвующее в нем, но и лицо, специально завербованное для участия в разовых или неоднократных специальных насильственных действиях. Речь идет о 
подрывных акциях, направленных на свержение законного правительства, изменение (ослабление) государства. Такие противоправные деяния не связаны с непосредственным участием в вооруженном конфликте, однако представляют серьезную угрозу для стабильности и безопасности государства.

В этом смысле действия наемников тесно связаны с международной террористической деятельностью. А.Н. Трайнин справедливо указывал, что это не только родственные, но и тесно связанные между собой явления. Из подобных организаций и банд выходят террористы, и сам террор является одной из функций этих организаций ${ }^{11}$.

Отечественный ученый юрист Е.Г. Ляхов в своей работе "Терроризм и межгосударственные отношения" убедительно показывает, что мехдународный терроризм представляет собой совокупность совершенных в условиях мира между государствами следующих деянй̆:

а) незаконное и преднамеренное совершение лицом (группой лиц) на территории государства насильственного акта в отношении пользующихся защитой, согласно мировому праву, иностранных государственных или международных органов, их персонала и транспорта;

6) организованное или поощренное иностранным государством на территории данного государства незаконное совершение лицом (группой лиц) насильственного акта в отношении национальных учреждений, политических и общественных деятелей, населения, объектов в целях изменения государственного и общественного строя, провокации международных конфликтов и войны ${ }^{12}$.

Статья 47 Протокола I и положения Конвенции 1989 года четко устанавливают критерии наемника. Во-первых, главным критерием определения наемника является материальное вознаграждение. Форма вознаграждения в нормах права не указана, но это гораздо выше выплачиваемого комбатантам того же ранга, входящим в личный состав вооруженных сил данной стороны. Во-вторых, наемник специально вербуется для участия в конкретном вооруженном конфликте и действительно участвует в таком конфликте. Важной представляется точка зрения российских юристов И.Н. Арцибасова и C.А. Егорова, которые отмечают, что в данном случае несущественньм является, где наемник завербован (за границей или на территории государства, в котором происходит вооруженный конфликт), а также кто его завербовал (специальная организация, частное лицо или представитель одной из воюющих сторон) ${ }^{13}$. В-третьих, наемник не является ни гражданином стороны, находящейся в конфликте, ни лицом, постоянно проживающим на территории, контролируемой стороной, находящейся в конфликте. У наемника отсутствует какая- 
либо правовая связь с государством, на территории которого происходит вооруженный конфликт. На территорию суверенного государства наемники переправляются (забрасываются) негласно, с соблюдением строгих мер конспирации или же официально прибывая в страну, например в качестве туристов, переходят на негласное положение и участвуют в противоправной деятельности. Поэтому одной из задач спецслужб и правоохранительных органов является выявление, предупреждение и пресечение деятеліности вербовочных пунктов (баз), вербовщиков, самих наемников, а также возможных каналов переправки “солдат удачи”, оружия, специальных средств, предназначенных для их противоправной деятельности. Данная задача является актуальной и, по-видимому, должна быть нормативно закреплена на уровне международного межведомственного и межучрежденческого сотрудничества компетентных органов. В-четвертых, наемник не послан государством, которое не участвует в вооруженном конфликте, для выполнения официальных обязанностей в качестве лица, входящего в состав его вооруженных сил. Данный критерий проводит различие между наемниками и военньми советниками. Последние направляются в иностранное государство на основе двусторонних соглашений для оказания помоши в создании вооруженных сил, подготовке военных кадров, обучении войск, но непосредственного участия в военньг действия $x$ они не принимают. В-пятых, наемник не входит в личный состав вооруженных сил стороны, находящейся в конфликте. Это обстоятельство позволяет провести четкое разграничение между наемниками и добровольцами. В отличие от наемников, участие добровольцев в военных действиях на стороне одного из воюющих правомерно. Основные положения, касающиеся добровольцев, были закреплены Гаагскими конвенциями 1907 года. Конвенция о правах и обязанностях нейтральных держав и лиц в случае сухопутной войны содержит норму, в соответствии с которой ответственность нейтральной державы не возникает вследствие того, что частные лица отдельно переходят границу, чтобы поступить на службу одного из воюющих (ст. VI). Важно отметить, что доброволец включается в личный состав вооруженных сил конкретного государства, и этот факт делает его законным комбатантом. Воюющая сторона ответственна за все действия, совершенные лицами из состава ее вооруженных сил (ст. 3 VI Гаагской конвенции 1907 г.). Нсходя из этого, воюющая сторона принимает на себя всю полноту ответственности за действия, совершенные добровольцем. Наемник не входит в личный состав вооруженных сил, и ни одно государство не готово признать его действия как собственные.

Таким образом, пять рассмотренных критериев определяют конкретного индивида, конкретную личность как наемника. Важным 
представляется тот факт, что критерии должны рассматриваться только в совокупности.

Наемники в соответствии с нормами международного права рассматриваются как уголовные преступники. Поэтому государства, на территории которых наемники совершили противоправные деяния, могут преследовать и судить их. Государства в своих национальных законодательствах также закрепили противоправность наемничестBa.

Еще в 1870 году в Англии был принят Акт о службе иностранному государству. Положения этого акта запрещали подианным Великобритании поступать на службу $\mathrm{k}$ иностранному государству для участия в военных действиях против другого государства, если Великобритания не находится с последним в состоянии войны. В Швеции в 1948 году был принят специальный закон, запрещающий вербовку в армию иностранного государства и незаконный выезд из страны с целью поступления на такую службу. Положения Уголовного кодекса США закрепляют противоправность наемничества ${ }^{14}$. Уголовный кодекс ФРГ предусматривает тюремное заключение на срок от трех месяцев до пяти лет за вербовку гражданина ФРГ на военную службу в интересах иностранного государства в военное или подобное ему учреждение или доставку его вербовщикам этого учреждения ${ }^{15}$.

В российском законодательстве противоправность и наказуемость наемничества закреплены в ст. 359 Уголовного кодекса. Само определение наемника содержится в примечании $\mathrm{K}$ указанной статье. На первый взгляд, данное определение близко к определению, содержашемуся в ст. 47 Протокола І. Однако детальный сравнительно-правовой анализ позволяет выявить ряд расхождений.

Во-первых, примечание к ст. 359 позволяет считать наемником не только лицо, принимающее участие в боевых действиях, но и лицо, чья деятельность непосредственно не связана с участием в боевых операциях, ими могут быть врачи, повара, техники, механики, специалисты по радиосвязи, переводчики. Во-вторых, согласно примечанию, наемником может быть признано лицо, являющееся гражданином стороны, участвующей в конфликте, но не проживающее постоянно на ее территории, или, наоборот, не являкщееся гражданином данной стороны, но постоянно проживающее на ее территории ${ }^{16}$. В-третьих, примечание не содержит важного квалифицирующего признака, в соответствии с которым можно провести различие между наемником и добровольцем. В соответствии с примечанием к ст. 359 наемник не входит в состав вооруженных сил стороны, за которую он сражается. При наступлении уголовной ответственности наемник не может ссылаться на исполнение приказа или распоряжения (в УК Россин данная норма закреплена в ст. 42), 
так как он не является комбатантом и не входит в личный состав воинских подразделений стороны, участвующей в конфликте.

В случае, когда лицо в государстве своего гражданства принимает участие в боевых действиях на стороне отрядов вооруженной оппозиции, то есть непосредственно участвует в вооруженном конфликте немеждународного характера, его действия в соответствии с существующими нормами нельзя квалифицировать как наемничество. Такие противоправные деяния следует оценивать в соответствии с нормами уголовного законодательства конкретного государства. Например, в УК России такие деяния охватываются составом, закрепленньм в ст. 208 "Организация незаконного вооруженного формирования или участие в нем”.

Таким образом, определение наемника, содержашееся в ст. 359 УК России, не в полной мере соответствует юридическим признакам, закрепленным в ст. 47 Протокола І. Выявленные несоответствия создают определенные трудности для ученых и юристов-практиков при исследовании и квалификации данного противоправного деяния. При доработке данной нормы следовало бы включить в примечание к ст. 359 УК России определение и признаки, квалифицируюшие наемника, содержащиеся в ст. 47 Протокола I.

\section{IV}

Значительное место в борьбе и противодействии наемничеству должно отводиться механизму сотрудничества государств. Разработка и совершенствование механизма сотрудничества в современный период приобретают не только теоретическое, но и практическое значение. От того, каким будет созданный механизм, как он будет урегулирован, зависят слагаемые успеха деятельности государств и их компетентных органов в борьбе с наемничеством.

Под механизмом сотрудничества следует понимать систему правовых и организационных мер, направленных. на реализацию достигнутых соглашений в сфере борьбы с наемничеством. Важное место в области борьбы с рассматриваемым противоправным явлением занимают международно-правовые и административно-правовые меры.

В самом общем виде механизм сотрудничества государств, закрепленный в Конвенции 1989 года, выглядит следующим образом.

Государство, имеющее основание полагать, что совершено, совершается или будет совершено противоправное деяние, связанное с наемничеством, информирует об этом непосредственно или через Генерального секретаря ООН заннтересованные государства. Государство в соответствии со своим национальным законодательством и международными соглашениями осуществляет необходимые меры 
на своей территории или на борту морских и воздушных судов, зарегистрированных в этом государстве, а также в отношении лиц, находящихся на территории этого государства. Какие конкретные меры и при каких условиях их может применять государство, в Конвенции не ухазано. Однако такие меры, как правило, подразделяются на три основные группы: общепредупредительные, административно-правовые (режимные) и правоохранительные.

К общепредупредительным следует отнести меры, выполняющие упреждающие функции: прогнозирование, сбор, обобщение и оценку информации, разработку и корректировку действующего законодательства и т.д.

Административно-правовые (режимные) меры призваны установить барьеры, затрудняющие противозаконные действия: усиление охраны складов с оружием, введение пропускной системы в определенные районы для проезда и пребывания, введение режима чрезвычайного положения и т.д.

Правоохранительные меры применяются $\mathbf{k}$ лицам, в отношении которых имеются достаточные основания полагать, что их противоправная деятельность связана с наемничеством: имеются кино- и фотодокументы, подлинные контракты о вербовке в качестве наемника, свидетельские показания и т.д. Такие лица заключаются под стражу, и проводится предварительное расследование.

Первые два вида мер осуществляются широким кругом государственных органов с привлечением местных жителей. Правоохранительные меры должны осуществляться исключительно компетентными органами (спецслужбами, правоохранительными органами и т.д.), в компетенцию которых входит подобного рода деятельность.

Государство, на территории которого находится предполагаемый преступник, уведомляет непосредственно или через Генерального секретаря ООН прежде всего государство, на территории которого было совершено преступление или против которого было направлено преступление или покушение на преступление. Кроме того, уведомляется государство, гражданство которого имеет физическое или юридическое лицо, против которого было направлено преступление или похушение на преступление. Следующим адресатом является государство, гражданином которого является предполагаемый преступник. В случае, если он лицо без гражданства, то информируется государство, на территории которого он обычно проживает. Более того, такая информация может быть направлена в любое другое заинтересованное государство, если возникнет какая-либо необходимость.

Критерии уведомления другого заинтересованного государства при возникшей необходимости Конвенция не закрепляет. По-видимому, такой стороной может быть государство, в котором предпо- 
лагаемый преступник открыл счет в банке, занимался бизнесом, ранее совершил преступление или отбывал наказание, где проживают его родственники, имеются близкие связи и т.д.

Недоработкой Конвенции является отсутствие содержания уведомления, то есть той информации, которая будет передаваться другому государству или направляться Генеральному секретарю ООН. Уведомление может быть: общим - фамилия, имя, отчество (или второе имя), год и место рождения, характер противоправной деятельности; подробным - помимо указанных данных необходимо представить информацию о семейном положении, наличии недвижимости, государствах, в которых предполагаемый преступник жил (или посещал), местах отбывания наказания, близких связях и т.д.

Для урегулирования выявленных пробелов и обеспечения более четкого и объективного обмена информацией между государствами и их компетентными органами целесообразно разработать дополнительный протокол к рассматриваемой Конвенции.

Положения Конвенции гарантируют задержанному лицу право связаться и встретиться с представителем своего государства, гражданином которого оно является, а лицу без гражданства - с представителем государства, на территории которого оно обьчно проживает.

Конвенция специально закрепляет, что на всех стадиях судебного разбирательства необходимо соблюдение беспристрастности и выполнения всех прав и гарантий, предусмотренных национальным законодательством.

Государство, на территории которого проходит судебный процесс, информирует о его окончательных результатах Генерального секретаря ООН, который направляет эту информацию заинтересованным государствам. Важно указать, что нормы Конвенции закрепили возможность выдачи (экстрадиции) предполагаемого преступника для судебного разбирательства или отбытия наказания.

В настоящее время нормами международного права не установлено четкой процедуры судебного разбирательства за преступления, связанные с наемничеством. Нерешенным является вопрос о том, какой судебный орган будет осуществлять разбирательство по конкретному делу. Здесь может быть несколько вариантов.

Привлечение к ответственности наемников осушествляется национальными судами в соответствии с юрисдикцией того государства, на территории которого совершено преступление, или на территории государства, где в ходе оперативно-розыскных мероприятий был обнаружен преступник. Другим вариантом может быть создание специального военного трибунала для суда над теми наемниками, которые совершили преступление на территории нескольких государств $^{17}$. Более того, учитывая опасность преступных деяний, свя- 
занных с наемничеством, судебное разбирательство может быть осуществлено создаваемым в настоящее время Международным Уголовньт Судом ООН. Однако в ст. 22 проекта Статута Международного Уголовного Суда ООН в перечне преступлений, относительно которых суд наделяется юрисдикцией, наемничество как противоправное деяние не закрепляется ${ }^{18}$. В комментарии к ст. 22 отмечается, что если Конвенция 1989 года вступит в силу до принятия настоящего Статута, то можно будет рассматривать вопрос о включении этой Конвенции в перечень преступлений. В комментарии предложена следующая редакция: "Суд может наделяться юрисдикцией в отношении преступлений, касающихся наемников, как они определены в ст. 2, 3 и 4 Международной конвенции о борьбе с вербовкой, использованием, финансированием и обучением наемников от 4 декабря 1989 г.".

Такая позиция представляется достаточно обоснованной, так как ст. 47 Протокола I закрепляет только квалифицирующие признаки наемника, а Конвенция 1989 года детализирует понятие наемника и объявляет наемничество и противоправные деяния, которые связаны с ним (вербовку, использование, финансирование или обучение), преступлением. Это принципиальное отличие содержания Конвенции 1989 года от ст. 47 Протокола I.

\section{V}

Вооруженные конфликты, происходящие на территории различных государств, подтверждают, что действия наемников наносят серьезный ушерб суверенитету, стабильности и безопасности государств. Поэтому государствам в области борьбы с наемничеством следовало бы сосредоточить основные усилия на следующих направлениях:

во-первых, для повышения эффективности сотрудничества государств и их компетентных органов заинтересованным сторонам необходимо принять меры с целью присоединения к Конвенции 1989 года;

во-вторых, государствам следует привести в соответствие с нормами международного права национальное законодательство, то есть конкретизировать или установить ответственность за наемничество, а также разработать или усовершенствовать административно-правовые режимы, способные предотвратить или затруднить совершение противоправных деяний, связанных с наемничеством;

в-третьих, для более детального регулирования механизма сотрудничества государств в борьбе с наемничеством целесообразно заключение двусторонних соглашений, включая межведомственные соглашения компетентных органов государств, осуществляющих противодействие наемничеству; 
в-четвертых, в связи с тем, что наемничество представляет собой непосредственную угрозу национальной безопасности и, по существу, является новьм элементом оперативной обстановки, особое внимание на внутригосударственном уровне следует сосредоточить на тесном взаимодействии национальных органов. $\mathrm{K}$ таким органам относятся спецслужбы, Министерство обороны, Министерство внутренних дел (юстиции) и внутренние войска, пограничные подразделения, авиакомпании, транспортные службы и др. Тахое взаимодействие должно быть нормативно закреплено ведомственными соглашениями (административньми договорами) и детализировано приказами и инструкциями соответствующих органов исполнительной власти.

Настоящая статья не может претендовать на исчерпывающий анализ рассматриваемой проблемы, так как противодействие наемничеству является сложной и многоплановой задачей всех государств и их государственных органов.

C. 35 .

${ }^{1}$ Соловьев С.М. Чтения и рассказы по истории России.- М., 1989.-

${ }^{2}$ Агибалова Е.В., Донской Г.М. История средних веков.- М., Просвещение, 1997.- С. 139, 143.

${ }^{3}$ Карамзин Н.М. История Государства Российского.- Т. 4-5.- М., 1991.- C. 263. 224.

${ }^{4}$ Пушкарев С.Г. Обзор русской истории.- М.: Наука, 1991.- С. 223-

${ }^{5}$ Сафонов А. Терроризм в кавказском регионе // Независимое военное обозрение.- 1998.- № 1.- С. 2.

${ }^{6} \mathrm{CM}$. Афтафьев Ю.Н. Наемничество - преступное орудие колониалистской политики // Советское государство и право.- 1978.- № 11.C. $113-117$.

${ }^{7}$ См. Клаузевиц К. О войне.- М., Логос, 1997.- С. 54-56.

${ }^{8} \mathrm{CM}$. Burmester $H$. The receuitment and use of mercenaries in armed conflicts // American journal of international law.-1978. - Vol. 72.- № 1.P. $43-44$.

${ }^{9}$ См. ОАЕ, Сборник документов. 1970 - 1977 гт.- Вып. 3.- М., 1976.

10 Арчибасов И.Н., Егоров С.А. Вооруженный конфликт: право, политика, дипломатия. - М.: Международные отношения, 1989.- С. 124.

1 Трайнин A.H. Терроризм как метод подготовки и провохации войн // Советское государство и право.- 1952.- № 3.- С. 34 .

12 См. Ляхов Е.Г. Терроризм и межгосударственные отношения. - М.: Международные отношения, 1991.- С. 27-28.

${ }_{13}$ См. Арцибасов И.Н., Егоров С.А. Указ. соч.- С. 124.

14 См. Блищенко И.П., Жданов Н.В. Наемничество - международное преступление // Советский ежегодник международного права. - 1979.- М.: Наука, 1980.- C. 148, 149. 
is Уголовный кодекс ФРГ. - М.: Юрнцический колледж МГУ, 1996.C. 86 .

16 Потапое A. Международная противоправность наемничества // Юридическая газета.- 1998.- № $2(324)$ - С. 4.

$"$ См. Apчuбacos H.H., Ezopos C.A. Указ. сод.- С. 126.

1. Doc. A/CN, 4/L. $490 .-$ P. $21-23$.

Cmambs nocmynusa в редакцию о янаape 19982.

\section{ПРЕЗНДЕНТ CША БНЛI КЛИНTOH В МГКМО}

2 сентя6ря 1998 г. во время государственного визита в Россню Президент CLUA Билл Клинтон посетил МГИМО(У) МЩД РФ и выступит там с докладом перед профессорами и студентами.

На снимке (слева направо): ректор МГИМО, профессор, доктор исторических наук, Чрезвычайный н Полномочный Посоя А.В. Торкунов, Президент США Бнли Клинтон и студентка МГИМО, дочь ректора Екатернна Торкунова.

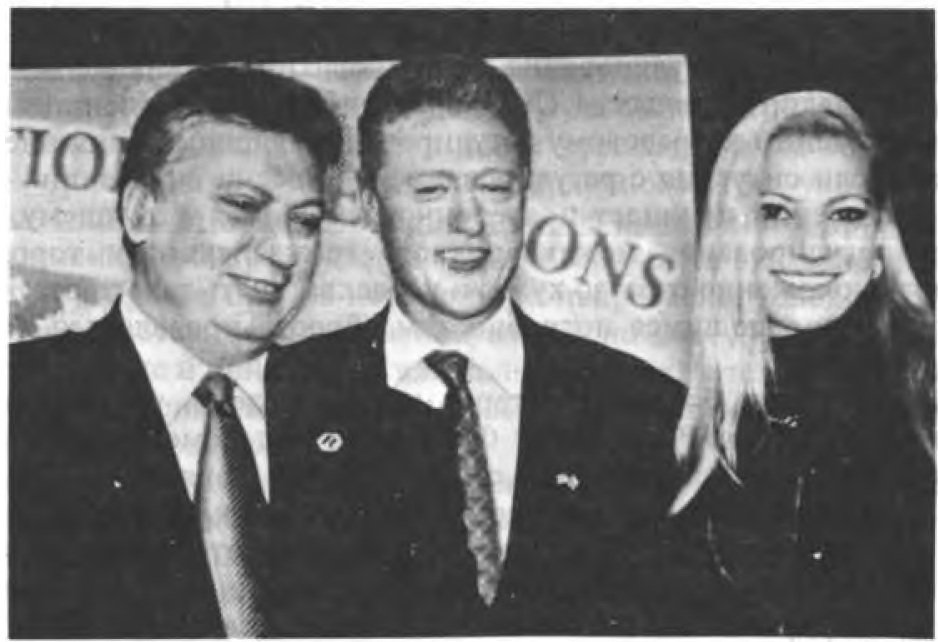

Фото Н. Лилеева 